\title{
Analisis Faktor-Faktor yang Mempengaruhi Penjualan "Waleu" Kaos Lampung di Bandar Lampung
}

\author{
Hendri Dunan', Muhammad Rizky Antoni², Heylin Idelia Jayasinga³, \\ Appin Purisky Redaputri ${ }^{4}$ \\ 1,2,3,4 Program Studi Manajemen, Fakultas Ekonomi dan Bisnis, Universitas Bandar Lampung \\ appin@ubl.ac.id
}

\begin{abstract}
Abstrak: Penelitian ini menganalisis faktor yang mempengaruhi penjualan Waleu Kaos Lampung dan mengetahui pengaruh antara Product, Price, Promotion, Place terhadap penjualan konsumen. Desain penelitian yang digunakan dalam penelitian ini adalah metode penelitian yang menggunakan pendekatan kuantitatif karena data yang akan digunakan untuk menganalisis hubungan antar variabel dinyatakan dengan angka atau skala numerik. Hasil penelitian Product berpengaruh positif dan signifikan terhadap penjualan; Place berpengaruh positif dan signifikan terhadap penjualan; Promotion berpengaruh positif dan signifikan terhadap penjualan; Place berpengaruh positif dan signifikan terhadap penjualan. Ini menunjukan bahwa Product, Price, Promotion, Place secara bersama-sama berpengaruh positif terhadap penjualan Pada "Waleu" Kaos Lampung Di Bandar Lampung sebesar $85,5 \%$ sisanya sebesar $14,5 \%$ dipengaruhi oleh faktor lain yang tidak penulis teliti. Untuk itu Waleu harus melakukan inovasi yang berfokus pada Product, Price, Promotion dan Place.
\end{abstract}

Kata Kunci: Analisa Faktor; Penjualan; Produk; Price; Place; Promotion

Abstract: $\quad$ This study analyzes the factors that affect the sales of Waleu Kaos Lampung and determine the effect of Product, Price, Promotion, Place on consumer sales. The research design used in this research is a research method that uses a quantitative approach because the data that will be used to analyze the relationship between variables is expressed by numbers or a numerical scale. Product research results have a positive and significant effect on sales; Place has a positive and significant effect on sales; Promotion has a positive and significant effect on sales; Place has a positive and significant effect on sales. This shows that Product, Price, Promotion, Place together have a positive effect on sales at "Waleu" Lampung Shirts in Bandar Lampung by $85.5 \%$, the remaining $14.5 \%$ is influenced by other factors that the authors do not examine. For this reason, Waleu must make innovations that focus on Product, Price, Promotion and Place.

Keywords: $\quad$ Factor Analysis; Sales; Product; Price; Place; Promotion

\section{PENDAHULUAN}

Provinsi Lampung merupakan salah satu dari sekian banyak daerah yang sering dikunjungi oleh para wisatawan. Hal ini didukung oleh program pemerintah yang mengajak wisatawan mengeksplorasi keindahan cagar alam dan budaya yang dimiliki oleh Provinsi Lampung. Wisata bahari, konservasi alam, taman rekreasi dan lain 
sebagainya merupakan beberapa tujuan alternatif pilihan yang bisa dikunjungi oleh para wisatawan tersebut.

Selain menikmati indahnya tempat pariwisata, para wisatawan yang berkunjung biasanya membeli produk kerajinan atau oleh-oleh khas daerah tersebut sebagai buah tangan yang akan diberikan kepada sanak saudara yang mereka miliki. Hal ini pun ditangkap sebagai pasar yang cukup potensial oleh pelaku usaha industri pariwisata dengan membuka toko oleh-oleh atau kerajinan tangan yang dapat memenuhi kebutuhan para wisatawan dalam hal produk lokal yang dijadikan buah tangan saat mereka berkunjung di suatu daerah.

Waleu Kaos Lampung adalah salah satu dari sekian banyak toko oleh-oleh berupa sandang dan aksesori pelengkap yang berciri khas ornamen budaya Lampung. Lokasinya berada di Jalan Wolter Monginsidi No. 89, Bandar Lampung. Letaknya cukup strategis, dekat dengan hotel berbintang, taman rekreasi, dan Kantor Pemerintahan Kota Bandar Lampung serta Pemerintah Provinsi Lampung.

Tabel 1. Data Persaingan Oleh-oleh Pakaian di Bandar Lampung

\begin{tabular}{|l|l|l|}
\hline No. & Nama Usaha & Pangsa Pasar \\
\hline 1 & Singgah Pai & $38 \%$ \\
\hline 2 & Waleu Kaos Lampung & $22 \%$ \\
\hline 3 & Ninda Shop & $20 \%$ \\
\hline 4 & Kawos Lampung & $25 \%$ \\
\hline 5 & Lain-Lain & $5 \%$ \\
\hline
\end{tabular}

Sumber: Asosiasi Pengusaha Oleh-Oleh Provinsi Lampung

Berdasarkan tabel 1.1 dapat dilihat bahwa data pesaing dari toko oleh-oleh Waleu Kaos Lampung adalah Singgah Pai Shop yang merupakan pemimpin pasar, kemudian Ninda Shop, Kawoz Lampung dan lain sebagainya. Meski tergolong baru dan belum bisa menjadi pemimpin pasar Waleu Kaos Lampung sudah dapat bersaing dengan toko oleholeh lainnya. Jika berbicara mengenai persaingan, harga merupakan alat yang menjadi kompetitif dalam bersaing. Harga merupakan satu-satunya elemen dalam bauran 
pemasaran yang menghasilkan pendapatan bagi perusahaan, oleh sebab itu harga dapat dikatakan mendatangkan laba bagi perusahaan (Mulyana, 2019). Berikut adalah produk dan harga yang ditawarkan oleh Gerai Waleu Kaos Lampung:

Tabel 2. Produk dan Harga Waleu Kaos Lampung

\begin{tabular}{|l|l|l|}
\hline No. & Produk & Harga \\
\hline 1 & Kaos/Polo Shirt Dewasa & Rp. 89.000 \\
\hline 2 & Kaos Sanak Lunik (Anak Kecil) & Rp. 58.000 \\
\hline 3 & Topi & Rp. 58.000 \\
\hline 4 & Tote Bag & Rp. 108.000 \\
\hline 5 & Jaket & Rp. 258.000 \\
\hline 6 & Sandal & Rp. 58.000 \\
\hline
\end{tabular}

Sumber: Waleu Kaos Lampung

Promosi salah satu hal penting yang berperan dalam mencapai keberhasilan usaha. Tujuan promosi adalah untuk meningkatkan kesadaran, menciptakan minat, menghasilkan penjualan, atau menciptakan loyalitas merek. Ini adalah salah satu elemen dasar dari bauran pasar, yang mencakup empat $\mathrm{P}$, yaitu, produk, harga, tempat, dan promosi (McCarthy, 1964). Pengenalan produk Waleu Kaos Lampung melalui promosi di kota Bandar Lampung melalui periklanan dan promosi penjualan. Kegiatan promosi yang dilakukan Waleu Kaos Lampung sangat penting sebagai sarana pemberi informasi dan mengingatkan sasaran produknya tentang sebuah keunggulan suatu produk sehingga dapat menarik minat pembelian terhadap produk Waleu Kaos Lampung. 
Tabel 3. Jumlah Target dan Realisasi Tahun 2013-2017

\begin{tabular}{|c|c|c|c|}
\hline Tahun & Target Penjualan & Realisasi & Presentase \\
\hline 2013 & $2000 \mathrm{pcs}$ & $1953 \mathrm{pcs}$ & $97,65 \%$ \\
\hline 2014 & $2100 \mathrm{pcs}$ & $1865 \mathrm{pcs}$ & $88,80 \%$ \\
\hline 2015 & $2200 \mathrm{pcs}$ & $2266 \mathrm{pcs}$ & $103 \%$ \\
\hline 2016 & $2300 \mathrm{pcs}$ & $2178 \mathrm{pcs}$ & $94,69 \%$ \\
\hline 2017 & $2400 \mathrm{pcs}$ & $2654 \mathrm{pcs}$ & $110,58 \%$ \\
\hline
\end{tabular}

Sumber: Waleu Kaos Lampung

Berdasarkan tabel 1.3 dapat dilihat bahwa terjadi fluktuasi pencapaian target penjualan bahkan penurunan penjualan yang cukup signifikan pada Waleu Kaos Lampung. Fluktuasi penjualan bisa dikarenakan berbagai macam faktor, sehingga terjadi fluktuasi pencapaian target penjualan. Berdasarkan target dan realisasi penjualan Waleu Kaos Lampung dari Tahun 2013 sampai dengan 2017 maka perlu diketahui lebih lanjut faktor-faktor yang mempengaruhi penjualan "Waleu” Kaos Lampung.

\section{TINJAUAN PUSTAKA}

\section{Penjualan}

Penjualan adalah mendapatkan seseorang untuk membeli salah satu produk, apakah dengan cara promosi atau secara langsung (Alma, 2002: 136). Penjualan merupakan salah satu kegiatan yang paling penting dari suatu perusahaan. Perusahaan tidak dapat berkembang dengan baik jika tidak mampu menjual produk yang dihasilkannya. Sebaliknya, jika perusahaan mampu untuk 10 terus meningkatkannya, maka perusahaan tersebut akan mampu eksis dalam persaingan usaha.

Secara umum ada tiga tujuan utama dalam kegiatan penjualan yaitu (Swastha dan Irawan, 2005: 404):

1. Mencapai volume penjualan tertentu.

2. Mendapatkan laba tertentu 
3. Menunjang pertumbuhan perusahaan

Dalam praktek penjualan, adakalanya kegiatan penjualan itu tidak berjalan lancar atau terjadinya penurunan volume penjualan. Adapun faktor-faktor yang mempengaruhi penjualan tersebut yaitu (Winardi,2001:2)

1. Faktor dari luar perusahaan antara lain:

a. Kebijakan Pemerintah Terutama di bidang ekonomi moneter dan perdagangan dapat mempengaruhi situasi penawaran dan permintaan barang dan jasa di pasar.

b. Perkembangan Ekonomi Dunia Dengan struktur ekonomi terbuka saat ini perkembangan ekonomi dalam negeri tidak dapat terlepas dari perkembangan ekonomi dunia, seperti perkembangan harga minyak internasional.

c. Perkembangan sosial ekonomi masyarakat Perubahan sosial ekonomi yang terjadi di masyarakat sangat berpengaruh terhadap pola permintaan mereka atas berbagai macam barang dan jasa.

d. Situasi persaingan Besar kecilnya situasi persaingan di pasar akan mempengaruhi kedudukan jasa masing-masing perusahaan yang bersaing.

2. Faktor dari dalam Perusahaan antara lain:

a. Kapasitas produksi pengadaan dana modal kerja paling sedikit untuk jangka pendek Kapasitas produksi yang dimiliki perusahaan akan membatasi kemampuan mereka dalam memproduksi barang dan jasa sampai jumlah tertentu.

b. Kesan pembeli terhadap hasil produksi Kesan pembeli terhadap barang dan jasa serta layanan yang mengiringinya sangat besar pengaruhnya terhadap kelancaran penjualan hasil produksi dimasa yang akan datang.

c. Kebijaksanaan harga jual Harga jual produk yang diterapkan perusahaan dimasa mendatang dapat menentukan kedudukan perusahaan dalam persaingan pada hal kemampuan perusahaan untuk bersaing akan mempengaruhi besar kecilnya jumlah penjualan barang dan jasa. 
Secara garis besar penurunan penjualan diakibatkan oleh:

1. Strategi atau kebijakan perusahaan, misalnya mutu atau kualias produk yang menurun, kenaikan harga yang terlalu tinggi, Sales Promosi yang dihentikan, pengurangan dana iklan yang cukup drastis.

2. Keadaan pasar, termasuk tingkat persaingan pada industri yang sejenis. Keadaan pasar bisa dipengaruhi oleh pesaing yang sedang melakukan program bonus, meluncurkan produk baru, meningkatkan dana iklan secara besar-besaran.

3. Karena Salesmen-nya, ketika mereka mulai malas atau demotivasi, atau tidak konsentrasi pada pekerjaan.

Konsep penjual berpendapat bahwa kalau konsumen dibiarkan begitu saja mereka tidak akan membeli produk organisasi dalam jumlah yang memadai. Oleh karena itu, organisasi harus melakukan usaha penjualan dan promosi yang agresif.

Konsep ini mengansumsi bahwa konsumen malas atau enggan melakukan pembelian dan juga diasumsikan bahwa perusahaan akan memiliki cara penjualan dan peralatan promosi yang efektif untuk merangsang lebih banyak pembelian. Kebanyakan perusahaan menganut konsep ini jika mereka kelebihan kapasitas.Tujuan mereka adalah menjual apa yang mereka hasilkan, bukan membuat apa yang diinginkan oleh pasar seorang pakar teori manajemen terbuka Peter Dructer menyatakan bahwa seseorang dapat mengonsumsikan bahwa selalu tetap dibutuhkan (Kotler, 2000: 16).

Penjualan akan tetap diperlukan namun tujuan pemasaran adalah memperlancar prosesproses penjualan itu. Pemasaran bertujuan untuk mengetahui dan memahami pelanggan sehingga barang atau jasa akan cocok dengannya dan dapat dijual dengan sendirinya. Idealnya pemasaran menyebabkan pelanggan siap membeli. Dengan demikian, yang dibutuhkan kemudian bagaimana membuat produk atau jasa tersedia di pasar (Kotler, 2000: 17). Adapun indikator dari penjualan menurut Kotler (1993, Hal: 30) antara lain :

1. Harga

2. Promosi

3. Kualitas

4. Produk 
5. Saluran distribusi

\section{Marketing Mix (Produk, Promosi, Harga dan Saluran distribusi)}

\section{Produk}

Pengertian produk adalah sekumpulan atribut fisik, psikologi layanan dan simbol-simbol yang menghasilkan kepuasan atau keuntungan bagi pembeli atau pengguna. Dapat diartikan bahwa produk adalah keseluruhan bentuk dari obyek atau proses yang memberikan nilai kepada konsumen, diman produk diklasifikasikan menjadi barang dan jasa. Ini berarti produk adalah segala sesuatu yang ditawarkan perusahaan untuk memuaskan kebutuhan atau keinginan dari para konsumrn. Produk adalah segala sesuatu yang dapat ditawarkan untuk mendapatkan perhatian, kemahiran, penggunaan, atau konsumsi yang mungkin memuaskan suatu kebutuhan dan keinginan. Kadang-kadang kita memakai istilah lain untuk produk, seperti penawaran (offering) dan pemecahan (solution) (Kotler, 2000:9). Produk juga didefinisikan sebagai apa saja yang dapat di tawarkan ke dalam pasar untuk diperhatikan, dimiliki, digunakan atau di konsumsi sehingga dapat memuaskan keinginan atau kebutuhan. Termasuk di dalamnya adalah obyek fisik, jasa, orang, tempat, organisasi dan gagasan. (Kotler and Amstrong 2000:6).

Untuk menentukan kualitas produk, menurut Kotler dan amstrong (2012:361) kualitas produk dapat dimasukkan ke dalam 9 dimensi, yaitu:

1. Bentuk (Form) produk dapat dibedakan secara jelas dengan yang lainnya berdasarkan bentuk, ukuran, atau struktur fisik produk.

2. Ciri-ciri produk (Features) karakteristik sekunder atau pelengkap yang berguna untuk menambah fungsi dasar yang berkaitan dengan pilihan-pilihan produk dan pengembangannya.

3. Kinerja (Performance) berkaitan dengan aspek fungsional suatu barang dan merupakan karakterisitik utama yang dipertimbangkan pelanggan dalam membeli barang tersebut.

4. Ketepatan/kesesuaian (Conformance) Berkaitan dengan tingkat kesesuaian dengan spesifikasi yang ditetapkan sebelumnya berdasarkan keinginan 
pelanggan. Kesesuaian merefleksikan derajat ketepatan antara karakteristik desain produk dengan karakteristik kualitas standar yang telah ditetapkan.

5. Ketahanan (durabillity) Berkaitan dengan berapa lama suatu produk dapat digunakan.

6. Kehandalan (reliabillity) Berkaitan dengan probabilitas atau kemungkinan suatu barang berhasil menjalankan fungsinya setiap kali digunakan dalam periode waktu tertentu dan dalam kondisi tertentu pula.

7. Kemudahan perbaikan (repairabillity) Berkaitan dengan kemudahan perbaikan atas produk jika rusak. Idealnya produk akan mudah diperbaiki sendiri oleh pengguna jika rusak.

8. Gaya (Style) Penampilan produk dan kesan konsumen terhadap produk

9. Desain (design) Keseluruhan keistimewaan produk yang akan mempengaruhi penampilan dan fungsi produk terhadap keinginan konsumen.

\section{Promosi}

Promosi dapat diartikan dengan berbagai kegiatan yang dilakukan perusahaan untuk mengkomunikasikan kebaikan produknya dan membujuk para segmen pasar untuk membeli produk tersebut (Kotler, 1999:236-237). Promosi juga dapat di definisikan sebagai serangkaian teknik yang digunakan untuk mencapai sasaransasaran penjualan atau pemasaran dengan penggunaan biaya yang efektif, dengan memberikan nilai tambah pada produk atau jasa baik para perantara maupun pemakai langsung, biasanya tidak dibatasi dalam jangka waktu tertentu.

Kotler (1999:20-21) mengatakan bahwa konsumen umunya enggan membeli, dan harus dipikat atau dimotivasi dengan promosi agar konsumen membeli lebih banyak. Oleh karna itu perusahaan harus mengeluarkan biaya promisi yang efektif dan tepat sasaran guna merangsang pembelian dalam jumlah yang lebih banyak.

Dalam promosi, ada 5 keputusan penting yang harus dihadapi, yang di kenal dengan 5M (Kotler, 1999:675), yaitu:

a) Mission, Apa yang menjadi sasaran atau tujuan dari promosi tersebut

b) Money, Seberapa besar anggaran untuk promosi 
c) Message, Pesan yang hendak di sampaikan dalam promosi

d) Media, Media yang akan dipakai (media cetak, atau elektronik)

e) Measurement, Bagaimana cara mengevaluasi hail promosi

Menurut Kotler dan Keller (2007:272) indikator-indikator dalam promosi di antaranya adalah:

1. Frekuensi promosi adalah jumlah promosi penjualan yang dilakukan dalam suatu waktu melalui media pomosi penjualan.

2. Kualitas Promosi adalah tolak ukur seberapa baik promosi penjualan dilakukan.

3. Kuantitas promosi adalah nilai atau jumlah promosi penjualan yang diberikan konsumen.

4. Waktu promosi adalah lamanya promosi yang dilakukan oleh perusahaan.

5. Ketetapan atau kesesuaian sasaran promosi merupakan faktor yang diperlukan untuk mencapai target yang diinginkan perusahaan.

\section{Harga}

Menurut Gilbert (2003:157) Harga is the monetery value assigned by the seller to something purchased, sold or offered for sale, or transactions by a buyer, as their wilingness to pay for the produk and channel services delivers". Kutipan ini berarti bahwa harga adalah harga nilai jual yang ditetapkan oleh penjual terhadap sesuatu yang terbeli, terjual, ditawarkan atau transaksi oleh pembeli, berdasarkan pada keinginan untuk membayar keuntungan produk. Pada umunya konsumen menyukai membeli pada toko eceran yang menawarkan berbagai macam produk dengan harga yang bersaing atau dapat dikatakan murah, minimal sesuai dengna produk yang hendak di konsumsi.

Harga secara implisit mempunyai hubungan dengan kualitas. Kualitas produk yang baik akan dijual dengan harga yang tinggi demikian juga sebaliknya. Dengan realitasnya, harga mempunyai pengaruh terhadap kepuasan konsumen. Harga memberikan pengaruh besar terhadap persepsi konsumen atas kualitas dan kepuasan konsumen itulah sebabnya, pemasaran hendaknya realistis (pantas) dalam menetapkan harga jual produk berikut layanannya. Kesalahan menetapkan harga jual akan berdampak pada persepsi konsumen yang kurang baik terhadap produk, layanan, dan perusahaan. Penetapan harga yang rendah dapat mencerminkan kualitas yang kurang baik, sebaliknya 
penetapan harga yang terlalu tinggi akan tidak memungkinkan konsumen untuk membelinya, sehingga konsumen akan beralih kepada produk pesaing atau produk subsitusi.

Dalam harga (harga) terkandung value, yang dikatakan bahwa mayoritas konsumen yang mencari value ketika mereka mebeli sebuah produk, yaitu nilai yang di peroleh di dapat dari kualitas produk dan harga itu sendiri. Sehingga dapat menambah nilai dari image atau brand produk maupun nama perusahaan tersebut (Gilbert, 2003:162). Jika seorang konsumen percaya citra dan kualitas dari sebuah produk itu baik, mereka akan berkeinginan untuk membuat pengorbanan yang besar untuk membeli produk tersebut.

Sedangkan menurut Kotler dan Bowen (2002:76) pengertian harga adalah sebagai berikut, sejumlah uang yang akan di kenakan atas barang atas jasa, lebih luasnya, harga adalah sejumlah nilai yang diberikan konsumen sebagai timbal balik atas keuntungan telah memiliki atau menggunakan produk atas jasa.

Menurut Stanton dan William (2003:59), pengerian harga adalah "Harga is the amount of money and or goods needed to acquire some combination of other goods and its companying service". Pengertian di atas mengandung arti bahwa harga adalah sejumlah uang dan atas barang yang dibutuhkan untuk mendapatkan kombinasi dari barang yang lain yang disertai dengan pemberian jasa. Harga merupakan elemen dari bauran pemasaran yang bersifat fleksibel, di mana suatu saat harga akan stabil dalam waktu tertentu tetapi dalam seketika harga dapat juga meningkat atau menurun dan juga merupakan satu-satunya elemen yang menghasilkan pendapatan dari penjualan.

Menurut Tjiptono (2006:67), keputusan bauran harga berkenan dengan kebijakan strategi dan taktis, seperti: tingkat harga, struktur diskon, syarat pembayaran dan tingkat diskriminasi harga dia antara berbagai kelompok pelanggan. Harga adalah jumlah uang (ditambah beberapa barang) yang dibutuhkan untuk mendapat sejumlah kombinasi dari barang beserta pelayanannya (Dharmmesta dan Irwan 2001:69). Harga suatu barang sangat mempengaruhi apakah suatu barang akan memasuki pasar atau tidak. Penetapan harga suatu barang bagi manajemen merupakan salah satu keputusan yang sangat penting karena harga akan di tetapkan harus dapat menutupi semua ongkos atau bahkan lebih dari itu yaitu untuk mendapatkan laba. Harga yang di tetapkan terlalu tinggi akan berakibat kurang menguntukan bagi perusahaan karen dapat mengakibatkan kerugian. 
Salah satu prinsip bagi manajemen dalam penentuan harga adalah menitikberatkan pada kemampuan pembeli atas harga yang telah ditetapkan dengan jalan untuk mendapatkan laba.

Kotler dan Amstrong (2012: 52) mengungkapkan bahwa di dalam indikator harga terdapat beberapa unsur kegiatan utama tentang harga. Indikator tersebut meliputi:
1. Daftar harga
2. Diskon
3. Syarat pembayaran
4. Potongan harga
5. Kredit
6. Periode pembayaran.

\section{METODE PENELITIAN}

Desain penelitian yang digunakan dalam penelitian ini pendekatan kuantitatif karena data yang akan digunakan untuk menganalisis hubungan antar variabel dinyatakan dengan angka atau skala numerik. Penelitian ini menganalisis faktor yang mempengaruhi mempengaruhi penjualan Waleu Kaos Lampung. Data dianalisis dengan menggunakan model regresi berganda (multi regression method) yang bedasarkan pada hubungan antara dua variabel yaitu variabeldependen dan variabel independen. Sebagai variabel independen yaitu Product $\left(X_{1}\right)$, Promosi $\left(X_{2}\right)$, Price $\left(X_{3}\right)$, dan place $\left(X_{4}\right)$. Sedangkan variabel dependen yaitu Penjualan (Y)

\section{a) Alat Analisis}

- Uji Validitas

Pengambilan kesimpulan jika nilai $\mathrm{r}$ hitung $>$ nilai $\mathrm{r}$ tabel maka butiran tersebut dikatakan valid atau menggunakan cut off point 0,3 jika nilainya lebih besar dari 0,3 dikatakan valid.

- Uji Reliabilitas 
Suatu variabel dikatakan reliabel, Ghazali dalam buku Duwi Priyatno (2013:30) apabila Hasil $\alpha>0,60=$ reliabel dan Hasil $\alpha<0,60=$ tidak reliabel.

- Regresi Linier Berganda

Untuk membuktikan ada atau tidaknya hubungan fungsional antara dua buah variabel bebas $(\mathrm{X})$ atau lebih dengan sebuah variabel terikat (Y). Rumus regresi linear berganda Duwi Priyatno (2010:61)

$\hat{Y}=a+b_{1} X_{1}+b_{2} X_{2}+\ldots . .+b_{n} X_{n}+e_{t}$

- Pengujian Hipotesis Secara Simultan (Uji - F)

Menurut pendapat (Sugiyono:2013) Uji F digunakan untuk menguji tingkat signifikan dari pengaruh variabel bebas secara bersama-sama terhadap variabel terikat.

- Pengujian Hipotesis Secara Parsial $(\mathrm{Uji}-\mathrm{t})$

Menurut Sugiyono (2008, p244) uji t pada dasarnya menunjukkan seberapa jauh pengaruh suatu variabel penjelas secara individual dalam menerangkan variasi variabel terikat.

- Koefesien Determinasi

Koefisien determinasi digunakan untuk menunjukan seberapa besar pengaruh antara kedua variabel yang diteliti, maka dihitung koefisien detrminasi (R) dengan asumsi faktor-faktor lain diluar variabel dianggap konstan/tetap (cinteris paribus).

\section{HASIL DAN DISKUSI}

\section{a. Regresi Linier Berganda}

Tabel 4.

Hasil Uji Regresi Linear Berganda

\begin{tabular}{|l|l|l|l|l|l|}
\hline Coefficients $^{\mathrm{a}}$ & \multicolumn{3}{l|}{} & & \\
\hline \multirow{2}{*}{ Model } & $\begin{array}{l}\text { Unstandardized } \\
\text { Coefficients }\end{array}$ & $\begin{array}{l}\text { Standardized } \\
\text { Coefficients }\end{array}$ & Sig. \\
\cline { 2 - 5 } & B & Std. Error & Beta & T & Sig \\
\hline
\end{tabular}




\begin{tabular}{|l|l|l|l|l|l|l|}
\hline 1 & (Constant) & 1.151 & 1.319 & & .873 & .385 \\
\cline { 2 - 7 } Product & .374 & .080 & .333 & 4.666 & .000 \\
\hline Price & .742 & .077 & .696 & 9.643 & .000 \\
\hline Promotion & .101 & .100 & .285 & 1.412 & .014 \\
\hline Place & .485 & .104 & .444 & 4.661 & .000 \\
\hline
\end{tabular}

Tabel 4. menunjukan bahwa modal regresi dapat dianalisis berdasarkan koefisienkoefisiennya. Model persamaan regresi linier berganda berdasarkan table 4 adalah:

$Y=1,151+0,374 X 1+0,742 \times 2+0,101 \times 3+0,485 X 4+e t$

Interpertasi:

a1,151mempunyai makna jika Product, Price, Promotion, Place,dianggap konstan maka penjualan sebesar $1,151 \%$.

$\beta 1=0,374$ mempunyai makna

Jika Productditingkatkan satu satuan/point dengan asumsivariabel lain tetap maka penjualan meningkat sebesar 0,374satuan/point.

$\beta 2=0,742$ mempunyai makna

Jika price ditingkatkan satu satuan/pointdengan asumsivariabel lain tetap maka penjualan naik sebesar 0,742satuan/point

$\beta 3=0,101$ mempunyai makna

Jika promotion ditingkatkan satu satuan/pointdengan asumsivariabel lain tetap maka penjualan naik sebesar 0,101 satuan/point.

$\beta 4=0,485$ mempunyai makna

Jika place ditingkatkan satu satuan/pointdengan asumsivariabel lain tetap maka penjualan naik sebesar 0,485 satuan/point.

\section{b. Analisis Koefisien Determinasi}


Analisis determinasi secara simultan digunakan untuk mengetahui pengaruh antara dua variabel atau lebih, sehingga dapat diketahui seberapa besar persentase variable $\mathrm{X}$ mempengaruhi Y

Tabel 5.

\section{Koefisien Determinasi Secara Simultan}

\begin{tabular}{|l|l|l|l|l|}
\hline \multicolumn{3}{|l|}{ Model Summary } \\
\hline Model & R & R Square & $\begin{array}{l}\text { Adjusted R } \\
\text { Square }\end{array}$ & $\begin{array}{l}\text { Std. Error of the } \\
\text { Estimate }\end{array}$ \\
\hline 1 & $.924^{\mathrm{a}}$ & .855 & .848 & 1.351 \\
\hline
\end{tabular}

Jadi dapat ditarik kesimpulan bahwa besarnya pengaruh Product, Price, Promotion, Place,terhadap penjualan sebesar 85,5\% ,Koefisien Penentu sangat besar, hal ini disebabkan para responden menjawab semua kuesioner dengan Sangat setujudan sisanya sebesar $14,5 \%$ dipengaruhi oleh faktor lain yang tidak penulis teliti.

\section{c. Uji Hipotesis Secara Parsial (Uji-t)}


Tabel 6.

Uji Hipotesis Secara Parsial

\begin{tabular}{|c|c|c|c|c|c|}
\hline \multicolumn{6}{|c|}{ Coefficients $^{\mathrm{a}}$} \\
\hline \multirow[b]{2}{*}{ Model } & \multicolumn{2}{|c|}{ Unstandardized Coefficients } & \multirow{2}{*}{\begin{tabular}{|l} 
Standardized Coefficients \\
Beta
\end{tabular}} & \multirow[b]{2}{*}{$\mathrm{T}$} & \multirow[b]{2}{*}{ Sig. } \\
\hline & $\mathrm{B}$ & Std. Error & & & \\
\hline 1 (Constant) & 1.151 & 1.319 & & .873 & .385 \\
\hline Product & .374 & .080 & .333 & 4.666 & .000 \\
\hline Price & .742 & .077 & .696 & 9.643 & .000 \\
\hline Promotion & .101 & 100 & .285 & 1.712 & .014 \\
\hline Place & .485 & .104 & .444 & 4.661 & .000 \\
\hline Denend & $\mathrm{V}$ & enjualan & & & \\
\hline
\end{tabular}

Positif 0,374 dengan nilai signifikansinya 0,000 lebih kecil dari nilai alpha $<0,05$. Secara statistik, berpengaruh terhadap penjualan. jika thitung $(4,666)>$ ttabel $(1,661)$ maka kesimpulan nya Ho ditolak dan Ha diterimadengan demikian Hipotesis pertama: "Product berpengaruh positif dan signifikan terhadap penjualan Pada "WALEU" KAOS LAMPUNG DI BANDAR LAMPUNG” diterima.

Positif 0,742 dengan nilai signifikansinya 0,000 lebih kecil dari nilai alpha 0,05. variebel price berpengaruh terhadap penjualan. jika thitung $(9,643)>\mathrm{t}$ tabel $(1,661)$ maka kesimpulan nya Ho ditolak dan Ha diterima dengan demikian Hipotesis kedua: "Price berpengaruh positif dan signifikan terhadap penjualan Pada "WALEU" KAOS LAMPUNG DI BANDAR LAMPUNG” diterima.

Positif 0,101 dengan nilai signifikansinya 0,014 lebih kecil dari nilai alpha 0,05. variebel Promotion berpengaruh terhadap penjualan. jika thitung $(1,712)>$ ttabel $(1,661)$ maka kesimpulan nya Ho ditolak dan Ha diterima dengan demikian Hipotesis ketiga: "Promotion berpengaruh positif dan signifikan terhadap penjualan Pada "WALEU" KAOS LAMPUNG DI BANDAR LAMPUNG” diterima. 
Positif 0,485 dengan nilai signifikansinya 0,000 lebih besar dari nilai alpha 0,05. variebel place tidak berpengaruh terhadap penjualan. jika thitung $(4,661)<\mathrm{t}$ tabel $(1,661)$ maka kesimpulan nya Ho diterima dan Ha ditolak dengan demikian Hipotesis keempat: "place berpengaruh positif dan signifikan terhadap penjualan Pada "WALEU" KAOS LAMPUNG DI BANDAR LAMPUNG” diterima.

\section{d. Uji Hipotensis Secara Bersama-sama (Uji-F)}

\section{Tabel 7.}

Uji Hipotesis Secara Simultan

\begin{tabular}{|c|c|c|c|c|c|c|}
\hline \multicolumn{7}{|c|}{ ANOVA $^{\mathrm{b}}$} \\
\hline \multicolumn{2}{|c|}{ Model } & Sum of Squares & df & Mean Square & F & Sig. \\
\hline Regression & 976.640 & 4 & 244.160 & 133.766 & $.000^{\mathrm{a}}$ \\
\hline Residual & 166.100 & 91 & 1.825 & & \\
\hline Total & 1142.740 & 95 & & & \\
\hline a. Predictors: (Constant), place, price, product, promotion \\
\hline \multicolumn{7}{|c|}{ b. Dependent Variable: penjualan } \\
\hline
\end{tabular}

Dari hasil perhitungan diketahui Nilai Fhitung sebesar 133,766 pada tingkat signifikansi 0,000a dengan menentukan tingkat kepercayaan 5\% dan derajat kebebasan df1 = 4 dan df2 $=91$, maka dari Ftabel didapat nilai 2,471. Oleh karena Fhitung lebih besar dari pada Ftabel, maka Ho ditolak dan Ha diterima dengan demikian Hipotesis: "Product, price, promotion, place secara bersama-sama berpengaruh positif terhadap penjualan Pada "WALEU" KAOS LAMPUNG DI BANDAR LAMPUNG" diterima. Hal ini sesuai dengan penelitian oleh Herlina (2008: 23) sebagai rujukan penulisan dengan meneliti judul: "Analisis Faktor-Faktor Yang Mempengaruhi Volume Penjualan Produk Obat Anti Nyamuk Bakar merek Garuda pada PT. Indomarco Cabang Bangkinang”. Dari hasil penelitian diketahui bahwa variabel bebas (produk, harga, promosi dan distribusi) mempunyai pengaruh secara bersama-sama terhadap volume penjualan pada PT. Indomarco Cabang Bangkinang. 
Selain itu penelitian ini juga sesuai dengan penelitian yang dilakukan oleh Yani (2009: 23-24) sebagai rujukan penulisan dengan meneliti judul: “Analisis Faktor-Faktor Yang Mempengaruhi Volume Penjualan Produk Spring Bed pada PT. Anugrah Karya Aslindo di Kecamatan Siak Hulu Kabupaten Kampar”. Kesimpulan yang diperoleh adalah diketahui bahwa variabel bebas (kualitas produk, tingkat harga, promosi dan persaingan) bersama-sama mempengaruhi volume penjualan pada PT. Anugrah Karya Aslindo di Kecamatan Siak Hulu Kabupaten Kampar.

\section{KESIMPULAN}

Dari penelitian diatas dapat dilihat kesimpulan berikut:

1. Product Berpengaruh Positif dan signifikan Terhadap Penjualan Pada "Waleu" Kaos Lampung Di Bandar Lampung.

2. Price Berpengaruh Positif dan signifikan Terhadap Penjualan Pada "Waleu" Kaos Lampung Di Bandar Lampung.

3. Promotion Berpengaruh Positif dan signifikan Terhadap Penjualan Pada "Waleu" Kaos Lampung Di Bandar Lampung.

4. Place Berpengaruh Positif dan signifikan Terhadap Penjualan Pada "Waleu" Kaos Lampung Di Bandar Lampung.

5. Nilai Fhitung Sebesar 133,766 Pada Tingkat Signifikansi 0,000a Ho Ditolak Dan Ha Diterima Dengan Demikian Hipotesis Kdelapan: "Product, Price, Promotion, Place Secara Bersama-Sama Berpengaruh Positif Terhadap Penjualan Pada "Waleu” Kaos Lampung Di Bandar Lampung"

\section{SARAN}

1. Waleu harus melakukan inovasi sesuai perkembangan jaman karena disaign selalu berkembang dan harus mengikuti perkembangan jaman

2. Memberikan list harga yang menarik dan memberikan promo tertentu setiap pembelian agar semakin menarik untuk meningkatkan penjualan.

3. Promosi di media internet untuk jaman sekarang cukup penting untuk memperluas jangkauan pemasaran produk waleu. 
4. Menambah fasilitas seperti lahan parkir dan kondisi ruangan agar pembeli nyaman ketika berbelanja dan memilih produk.

\section{ACKNOWLEDMENTS}

Penelitian ini didukung oleh Universitas Bandar Lampung.

\section{DAFTAR PUSTAKA}

Buchari, A. (2002). Manajemen Pemasaran dan Pemasaran Jasa. Bandung : CV. Alfabeta.

Dharmmesta., Irawan. (2001). Manajemen Pemasaran Modern, Edisi Kedua. Yogyakarta.

Gilbert, D. (2003). Retail Marketing Management, Second Edition. Prentice Hall.

Stanton, William J. (2003). Prinsip Pemasaran (terjemahan). Edisi 7,jilid 1. Jakarta: Erlangga.

Herlina, M. (2008). Analisis Faktor-faktor Yang Mempengaruhi Volume Penjualan Produk Obat Anti Nyamuk Bakar Merek Garuda Pada PT. Indomarco Cabang Bangkinang, Skripsi UIN Suska Riau Tidak di Publikasikan

Kotler, P. (2000). Manajemen Pemasaran. Jakarta. PT. Prenhallindo.

Kotler P. (1999). Manajemen pemasaran di Indonesia. Edisi 1. Jakarta: Salemba Empat.

Kotler. (1993). Manajemen Pemasaran (Analisis perencanaan, implementasi dan pengendalian). Jakarta: Lembaga Penerbit Fakultas Ekonomi Universitas Indonesia.

Kotler, P. (1997). Manajemen Pemasaran Analisis Perencanaan, Implementasi dan Pengendalian (terjemahan Jaka Wasana). Jakarta: Salemba Empat.

Kotler, P. (2000). Manajemen Pemasaran. Jakarta. PT. Prenhallindo.

Kotler, P., John., B dan James, M. (2002). Pemasaran Perhotelan dan Kepariwisataan, Versi Bahasa Indonesia, Edisi Kedua, Jilid 2. Jakarta: Prenhallindo.

Kotler dan Keller. (2007). Manajemen Pemasaran, Edisi 12, Jilid 1.Jakarta: PT.Indeks.

Kotler, Amstrong. (2012). Prinsip-prinsip pemasaran, Edisi keduabelas, Jilid 1. Jakarta: Erlangga. 
Kotler, P dan Armstrong, G. (2012). Principles of Marketing. New Jersey: Prentice Hall.

McCarthy, J.E. (1964). Basic Marketing. A Managerial Approach. Homewood, Illinois: Irwin. pp. $\underline{769} . \underline{I S B N} \underline{0256025339}$.

Mulyana, M. (2019). Strategi Penetapan Harga. Manajemen Pemasaran. Universitas Terbuka.

Swastha, B., Irawan, (2005). Asas-asas Marketing. Yogyakarta: Liberty.

Tjiptono, F. (2006). Manajemen Pelayanan Jasa. Yogyakarta: Penerbit Andi.

Winardi. (2001). Motivasi \& Pemotivasian dalam Manajemen. Jakarta : PT. RajaGrafindo Persada.

Yani, A. (2009). Analisis Faktor-faktor Yang Mempengaruhi Volume Penjualan Produk Spring Bed Pada PT. Anugrah Karya Aslindo di Kecamatan Siak Hulu Kabupaten Kampar, Skripsi UIN Suska Riau Tidak di Publikasikan. 